\title{
Analysis of Leadership Styles in Banking Sector in North Cyprus: Testing Factors Effecting Authoritarian Style and a Model for Banking Sector in a Small Island Economy
}

\author{
Ahmet Melih Karavelioğlu \\ Girne American University \\ Kazım Nami Duru Sok 8/A Ortaköy Lefkoşa KKTC, Turkey \\ E-mail: ahmet.karavelioglu@iktisatbank.com
}

Received: September 29, 2014 Accepted: October 26, $2014 \quad$ Published: October 28, 2014

doi:10.5296/ijrd.v1i1.6513 URL: http://dx.doi.org/10.5296/ijrd.v1i1.6513

\begin{abstract}
Analysis of the Leadership Styles in Turkish Republic of Northern Cyprus Banking Sector, test some hypotheses related to leadership styles and test the model which explains the effect of task oriented and people oriented factors to the authoritarian behavior of managers in Banking sector in a small island economy is the main purpose of this research.

A total number of 177 usable questionnaires were personally retrieved from managers in the research premises. The hypothesized relationships were tested using descriptive statistics in SPSS version 16. Overall, the results reveal that managers in the north Cyprus banking sector exhibit task-oriented leadership style. Importantly, while the older managers were found to be less people-oriented leaders, on the other hand, younger managers were found to be more task-oriented leaders. Contrary to the previous findings, the female managers were found to be more task-oriented leaders in this context. This research makes useful contributions to the current knowledge base and the related industry by exclusively generating a new model for the small island economies.
\end{abstract}

Keywords: North Cyprus, banking sector, leadership style, island economies, Authoritarian behavior

\section{Introduction}

During the past four decades, the impact of leadership styles on organizational performance 
has been a topic of interest among academicans and practitioners working in the area of leadership (Cannella \& Rowe, 1995; Giambatista, 2004; Rowe et al., 2005). Perhaps the most prominent reason for this interest is the widespread belief that leadership can affect the performance of organizations (Rowe et al., 2005 p, 197; Ulgen \& Mirze 2006). Critical organizational outcomes, such as satisfaction, organizational performance, group performance, and commitment, have been associated with these leadership styles (Kirkpatrick \& Locke, 1996).

The style approach focuses on what leaders do rather than who leaders are. It suggests that leaders engage in two primary types of behavior: task behaviors and relationship behaviors. How leaders combine these two types of behavior to influence others is the central purpose of the style approach. The goal has been to find a universal set of leadership behaviors capable of explaining leadership effectiveness in every situation. (Northouse, 2004 p, 65-83) Researchers studying the style approach determined that leadership is composed of essentially two general kinds of behaviors: task behaviors and relationship behaviors. (e.g., Koçel, 2005; Mullins, 1993; Northouse, 2004).Task-oriented behaviors facilitate goal accomplishment. Relationship behaviors help subordinates feel comfortable with themselves, with each other, and with the situation in which they find themselves. The central purpose of the style approach is to explain how leaders combine these two kinds of behaviors to influence subordinates in their efforts to reach a goal. In this regard, especially nowadays, for a sustainable competitive advantage it is important for the companies to differentiate themselves from others. This process may be crucial for a company. During this process in order to take the right decision, decision makers/leaders need new tools and methodologies to help to deal with uncertainties and to decide on the right strategies. Finding a methodology or a tool which make possible the creation and implementation of strategies for growth, diversification, or differentiation is important. When the future is truly uncertain, making systematically sound strategic decisions under uncertainty requires an approach. Understanding Leadership theories and styles may be helpful for the leaders to take a different approach which may create sustainable competitive advantages. Different styles of leadership should be developed in accordance with the shape of organization, followers' situation, ability and enthusiasm, external factors, culture of the nation etc.

According to the criteria set by United Nations (1978) a small nation is described as a country that has one of the following characteristics; a geographic area of less than $10.000 \mathrm{~km} 2$, a population of less than 1 million and GDP of less than 5.000 USD. Small island economies have a narrow resource base, a limited domestic market and high dependence on imports (Katırcioğlu, 2000). TRNC's population is 286.257 (de-jure population) as of 2011 census which was held on $4^{\text {th }}$ December 2011. The total area of the Cyprus, which is the third biggest island of Mediterranean, is approximately $9.252 \mathrm{sq} \mathrm{km}$, but TRNC covers a total area of $3.515 \mathrm{sq} \mathrm{km}$. GDP is around 6.327 million USD.

As a case in point, in a small island economy such as North Cyprus, decisions and style of the leader is getting more importance because they have to deal with the other problems which their counterparts do not face. For a relatively small population, North Cyprus tends to have a large number of banks as well as bank branches. The large number of banks in the North 
Cyprus has led to a branch density of 1 branch for every 1.276 people and this force the bank managers to take place in a severe competitive working environment. Due to the small economic scale and population limitations, it is difficult to find well- trained human resources and therefore rather than adopting task-oriented leadership approach, people-oriented leadership approach may be assumed to be more effective, efficient, and contemporary in such contexts.

The first duty of a business manager is to strive for the best possible economic results from the resources currently employed or available. (Drucker, 2006, p. 81) From this point, it can be stated that leadership style affects the performance of the organization as well.

Against this backdrop, this study aims to examine the leadership styles among managers at functional levels in banking sector as its setting and generate a model for top management of the Local banks and also managers of international banks which is called as the branch banks in North Cyprus. In order to maintain and increase the high leadership standards at banking sector, the current study findings contributes to the both the top management and the employees of the Banking sector who will be tomorrow's leaders in banking sector of North Cyprus. To date, much of the researches on leadership style have been conducted in the Western countries other than small island countries. Therefore, this study, being conducted in North Cyprus sought to expand this line of research by including different cultural context.

\section{Theoretical Background and Research Hypothesis}

\subsection{Concept of Leadership}

Leadership has probably been written about, formally researched and informally discussed more than any other single topic in the management and organization literature (Daft, 1998; Luthans, 1995). Review of leadership research shows that, there are almost as many different definitions of leadership as there are people who have tried to define it. (Koçel, 2005; Northouse, 2004; Stogdill, 1974). Despite all this attention given to leadership, there is still considerable controversy. Some organizational behavior theorists do not even recognize leadership. (Luthans, 1995) and in the past 50 years, there have been as many as 65 different classification systems developed to define the dimensions of leadership (Fleishman et al., 1991).

Despite all of these definitions changing for everyone, controversial, vague, even rejecting definitions many scholars shares the same idea and has common point for the basic characteristics of leadership such as; leadership is a group phenomenon, leaders use their influence to guide groups through a certain course of action leadership then requires influence or persuasion, leadership is goal directed and the presence of a leader often assumes some form of hierarchy in a group. The leaders are at the top of that hierarchy, even when the hierarchy is very flat (Bass, 1967; Koçel, 2005; Northouse, 2004; Yukl, 1994).

A review of the leadership literature reveals an evolving series of schools of thought from "Great Man" and "Trait" theories to "Transformational" leadership. There are "trait, behavioral, situational and attribution theories, visionary, ethical, charismatic, and transactional versus transformational" theories also (Abramson, 2007). 
Classical leadership theories have evolved through the 20th century from personality based, to behavioral to context based theories (Nahavandi, 2006).

One of the most extensive research studies on behavioral categories of leadership was held in the Ohio University started from 1945. After the studies researchers found two factors in a wide variety of studies encompassing many kinds of leadership positions and contexts. These were; consideration and initiating structure. Initiating structure behaviors were essentially task behaviors, including such acts as organizing work, giving structure to the work context, defining role responsibilities and scheduling work activities. Consideration behaviors were essentially relationship behavior and included building respect, trust, liking between leaders and followers. These two factors were playing important role for, how leaders carry out their leadership function. In simple terms, the Ohio State factors are task or goal orientation and recognition of individual needs and relationships. (Koçel, 2005)

While researchers at Ohio State were developing the Leader Behavior Description Questionnaire (LBDQ), researchers at the University of Michigan were also exploring leadership behavior, giving special attention to the impact of leaders' behaviors on the performance of the small groups during the same times (Northouse, 2004).

Researchers, who had summarized the findings of the University of Michigan studies, used the term employee-centered and production-centered supervisors. Like consideration and structure, employee-centered and production-centered supervision need to be balanced. Both the Ohio State studies and the University of Michigan studies appear to support the idea that there is no single behavioral category of leadership which is superior. There are many types of leadership behavior and their effectiveness depends upon the variables in any given situation. (Mullins, 1993 p, 241)

\subsection{Task vs. People Oriented Leadership Styles}

The recognition of task and relationships as two important dimensions of Leader behavior has pervaded the works of management theorists over the years. These two dimensions have been variously labeled as "autocratic", and "democratic", "authoritarian" and "equalitarian", "employee oriented" and "production oriented", "goal achievement" and "group maintenance", "task ability" and "likeability" "instrumental and expressive" "efficiency and effectiveness" ( Hersey \& Blancard, 1969 p, 188). According to Bass and Stogdill (1990), Leaders differ in their concern for the groups' goals and the means to achieve the goals. Those with a strong concern are considered to be task oriented (Bass, I967; Fiedler, 1967), concerned with production (Blake \& Mouton, 1964)

Leaders also differ in the extent to which they pursue a human relations approach and try to maintain friendly, supportive relations with their followers. Those with a strong concern are identified as relations oriented (Katz et al., 1950), concerned for people (Blake \& Mouton, 1964), people centered (Anderson, 1974; Bass \& Stogdill, 1990, p. 472).

As it is seen from the above given literature review, different names are given to the leadership styles in conjunction of the leader behavior or relation with the follower. In this article task oriented Leadership style description is given to those who have a strong concern 
for task and people oriented leadership style description is given to those who have a strong concern for people in order to reach a common goal.

\subsection{The Banking Sector in TRNC}

The TRNC financial system consists of the Central Bank, commercial banks (State, National and foreign banks) and an investment bank. In terms of total assets, the total share of first ten banks was $79.07 \%$ as of March 2014. With regard to ownership, commercial banks can be grouped as state, private and foreign banks. State owned banks controlled $29.16 \%$ of total assets and privately owned banks controlled $40.67 \%$ and foreign (so called branch banks) $30.17 \%$ of total assets respectively (Central Bank of TRNC Quarterly Bulletin, 2014).

It is important to note that amongst the largest banks in North Cyprus commercial banking sector, there are 2 state-owned banks, one of which is a cooperative bank. Investment bank is established to extend medium and long-term loans to certain industries such as tourism and education-especially the development of dormitories and tourism investments in North Cyprus and they are funded by the other commercial, state owned and foreign banks by regulation.

It is difficult to mention a banking sector or a financial system, without existence of Central Bank. After peace operation of 1974, the Cyprus Island was divided in to two sections: South and North. The young republic of was established on 15 November 1983 and so far recognized only by Turkish Republic. Central Bank law of has been passed from the assembly on $16^{\text {th }}$ May 1983 and Central Bank of was established on $6^{\text {th }}$ June 1984 with 43 employees (Central Bank of web site).

Central bank of has been restructured after the crisis of 1999 and 2000 and new Banking law has been passed from the assembly of TRNC in 2001.

The banking system is unique from other banking systems within the same scale countries such as Malta, South Cyprus, and Luxembourg etc. First, banks which operate in North Cyprus especially the Local banks are under a limitation and their only gateway to the outside world is through the banks in Turkey because of the embargo applied by the world after 1974 peace operation. National or local banks in North Cyprus do not have or minimal correspondent relations with international banks. Local banks do not have ability to reach the international markets to reach the cheaper funds. The only gateway to the international payment system is via banks in Turkey, some of them also competitors in the same market in North Cyprus.

The limitations of North Cyprus banks from worldwide organizations such as SWIFT (a secure electronic fund transfer and communication system among international banks) and the card payment companies such as visa and MasterCard also creates major problems and extra financial burdens to local banks. All the international incoming and outgoing transfers in or out from the country for the import and export of goods, are done via banks located in Turkey. There are also foreign banks which operate in North Cyprus with their international brand names such as HSBC, ING or TEB (BNP Paribas has shares) and Garanti (Genaral Electrics which is an American conglomerate had shares) which have international 
shareholders. There are also two state banks of Turkey namely Halk Bank and Ziraat Bank whose shares are hold by treasury of Turkish Republic. All these international banks have facilities to reach the international market for the borrowing of cheaper funding while local banks' only source for funding is the deposits. Technologically local banks' have serious investments to compete with the international brands, they try to increase their capital adequacy ratio and they are under high competition with the international banks performing in the same market. This situation will help the local banks to increase their competitiveness in case of a solution of Cyprus problem.

After the crisis in 2000 and 2001 number of banks dropped drastically from 39 in 2000 and 37 in 2001 to 22 in 2013 (Karavelioğlu, 2009). The banking crisis, which occurred at the beginning of the year 2000, has resulted in the liquidation of ten banks and ended up with economic losses of approximately 200 trillion TL, almost equivalent to 50\% of GNP for 1999 . The main reason for such huge losses for the TRNC economy is due to the fact that the commercial banks and the institutions responsible for regulation, monitoring, supervision of the financial sector together with those running the monetary policies did not have an organizational appreciation of proactive strategies (Şafaklı, 2003).

TRNC tends to have a large number of banks as well as bank branches. Currently the TRNC has 15 national in which 2 of the listed as state owned and 7 foreign banks for 286.257 population.

Table 1. Distribution of banks

\begin{tabular}{|c|c|}
\hline Sector & Number \\
\hline State Banks & 2 \\
\hline National Banks & 13 \\
\hline Foreign Banks & 7 \\
\hline Total & $\mathbf{2 2}$ \\
\hline
\end{tabular}

Source: Central Bank of TRNC Bulletin March 2014.

In terms of bank branches, domestic banks have a total of 178 branches, an average of 12 branches per bank. On the other hand Foreign banks have 48 branches and limited to an average of seven branches per bank. Currently, there are 2840 employees in banking sector, 2280 are employed in national banks while 560 are employed in Foreign Banks. In other words only $20 \%$ are employed by foreign banks while $80 \%$ are employed by national banks. (Central Bank of TRNC Quarterly Bulletin, March, p. 19).

The large number of banks in the TRNC has led to a branch density of 1 branch for every 1.276 people while in Turkey this number is 7,444 (end of 201275.625 .000 estimated population while 10.158 branch numbers in Turkey) (compiled from the data at www.tbb.org). 
Table 2. Branch and employee numbers of banks in TRNC

\begin{tabular}{|l|l|l|}
\hline Sector & Branch Number & Employees \\
\hline State Banks & 38 & 528 \\
\hline National Banks & 140 & 1752 \\
\hline Foreign Banks & 48 & 560 \\
\hline Total & $\mathbf{2 2 6}$ & $\mathbf{2 8 4 0}$ \\
\hline
\end{tabular}

Source: Central Bank of TRNC Bulletin March 2014.

Total asset size of the banking sector in TRNC is 13.287 million TL (approximately 6.327 million USD) as of March 2014 and total deposits are 10.708 TL (approximately 5.099 million USD) and total credits size is 8.456 (approximately 4.026 million USD) First five banks holds the $55 \%$ of total assets and $59 \%$ of total credits.

Gross Domestic Product of TRNC is 9.038 million TL (estimated figure as of 2013 - this can be given as an example of the insufficient data or lack of updated information in TRNC which is a restriction of the thesis- which means 4,304 million USD. Compared with total asset size of TRNC Banking sector with total GDP as of 2014 March, TRNC Banking sector's total asset size (13.287 billion TL equivalent of 6.327 million USD) is approximately 1.47 times bigger than the GDP (Central Bank of TRNC Quarterly Bulletin p. 18).

Table 3. Employee density comparison with Turkey

\begin{tabular}{|l|l|l|l|l|}
\hline & TRNC & Turkey & National Banks & $\begin{array}{l}\text { Foreign } \\
\text { Banks }\end{array}$ \\
\hline $\begin{array}{l}\text { No Of } \\
\text { Employees }\end{array}$ & 2.840 & 198.307 & 2.280 & 560 \\
\hline No Of Branches & 226 & 11.055 & 178 & 48 \\
\hline $\begin{array}{l}\text { Employee Per } \\
\text { Branch \% }\end{array}$ & 12.57 & 17.94 & 12.81 & 11.67 \\
\hline
\end{tabular}

Source: Compiled from data at Central Bank of TRNC and Turkish Banks Association March 2014.

Table 9 show the comparison of employee density with Turkey. In TRNC there are 12.6 employees per branch while in Turkey almost 18 employees per branch. However, when we look the employee numbers of foreign banks in TRNC this number drops 11.7 employees per branch while in National banks there is similar result, 12.8 employees per branch. This shows that National Banks has disadvantage, considering the personnel cost. This may be result of International banks does not have headquarters in TRNC they operate with branches only and take the support from the headquarters from Turkey.

\subsection{Proposing Conceptual Model and Hypotheses Design}

Leaders during their leadership process show task and people oriented behaviors. As mentioned before in the article, there are a lot of factors which affect the leaders during their 
leading process to behave authoritarian or democratic.

Derived from the questionnaire some factors, which will be explained in details later, found and below depicted model is constructed to test.

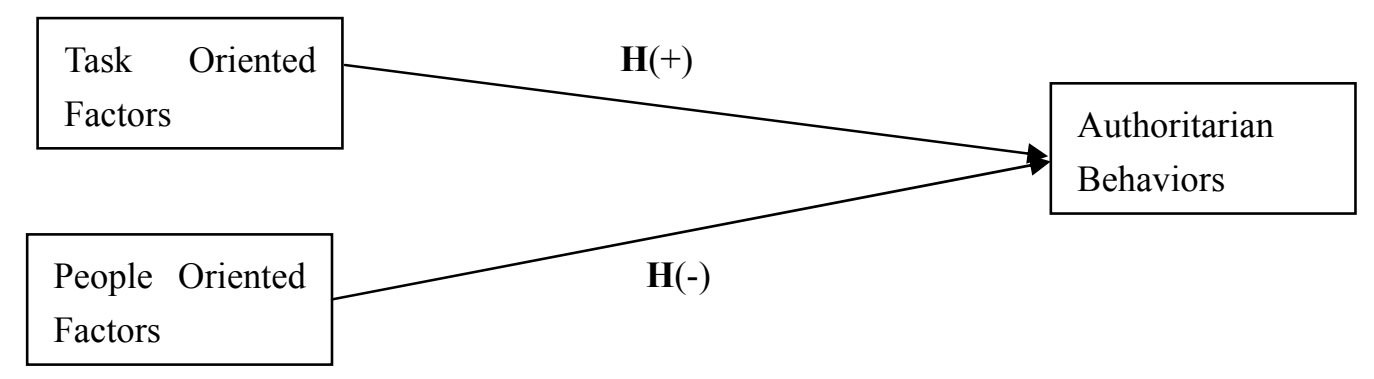

Figure 1. Proposed model for task and people oriented factors effect on authoritarian behaviors

Hypotheses related with the below shown model to be tested are given below:

H1. Task oriented factors exert significant effects on authoritarian behaviors;

H2. People oriented factors exert significant effects on authoritarian behaviors, In the research, for the purpose of testing before stated objectives below hypotheses are also structured;

H3. Managers in the banking sector display task oriented action;

H4a. International bank's managers' shows more task oriented leadership style;

H4b. Local bank's managers' shows more people oriented leadership style;

H5. Managers with higher education level tend to be more people oriented leadership style;

H6a. Male managers behave more tasks oriented leadership styles;

H6b. Female managers behave more people oriented leadership styles;

H7a.Older managers behave more people oriented leadership styles;

H7b Younger managers behave more task oriented leadership styles.

\section{Method}

\subsection{Data Collection and Sampling}

There are 2840 employees in banking sector as of March 2014. The target population was full-time bank employees, working in managerial positions in North Cyprus. Since people who have manager title or upper than manager title in the banks in North Cyprus are taken as target population for the research, sample size is limited. With the assumption of $10 \%$ of the employees has managerial title in the banking sector, the sample size of the research is approximately 285 . Before making any attempt to collect data from the banks, the research team contacted the managers of two particular banks in which they have personal relations to pilot-test the questionnaire with five managers. Following the pilot-study, the research team 
decided not to make any changes to the original questionnaire either in terms of format or content. Non-probability convenience sampling was conducted in this research. A total number of 250 received the questionnaire along with a cover letter and information about the assurance of confidentiality and anonymity. The questionnaires were conducted on a face-to-face and email connection basis. Of the 250 questionnaires, 177 were obtained, yielding a response rate of $71 \%$.

\subsection{Questionnaire Development and Measures}

One source in the previous literature was used while preparing the questionnaire for the current research. The questions of the survey were initially prepared in English and then translated to Turkish using the back-translation method (McGorry, 2000). The survey instrument used for this study was organized into two parts. The first part consists of questions relating to leadership styles. Based on an extensive literature review, measurement for the related construct was measured by thirty five items developed by Mullins (1993). All measures used a five-point Likert-type scale that ranged from ' 5 ' = 'always' to ' 1 ' = 'never'.

The second part of the survey was composed of four demographic questions: age, gender, education, and nationality. All of them were measured using four-point scales. Gender, on the other hand, was coded as a dichotomous variable $(0=$ male and $1=$ female $)$.

\subsection{Data Analysis}

The Statistical Package for Social Sciences Version 16 was used to explore the data. As for statistical techniques, firstly, reliability (Cronbach's alpha) and validity tests were conducted. Next, mean score was employed to observe average responses.

\section{Results}

\subsection{Psychometric Properties of the Measures}

The Statistical Package for Social Sciences Version 16 was used to assess the task oriented and people oriented styles of managers. As for statistical techniques, firstly, reliability (Cronbach's alpha) and validity tests were conducted. Cronbach's alpha is an index of reliability and associated with the variation accounted for by the true score of the "underlying construct" construct is the hypothetical variable that is being measured. (Hatcher, 1994) Alpha coefficients ranges from 0 to 1 and Nunnaly (1978) has indicated that 0.7 to be an acceptable reliability coefficient but lower thresholds are sometimes are used in the literature. De Vellis, (1991) points out the scores above the 0.6 as accepted level. 
Table 4. Reliability results

\begin{tabular}{|c|c|c|c|c|c|}
\hline \multicolumn{2}{|c|}{ Task Oriented } & \multicolumn{2}{|c|}{ People Oriented } & \multicolumn{2}{|c|}{ Total Scale } \\
\hline$\downarrow$ & & 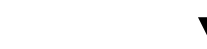 & & & \\
\hline \multicolumn{2}{|c|}{ Reliability Statistics } & \multicolumn{2}{|c|}{ Reliability Statistics } & \multicolumn{2}{|c|}{ Reliability Statistics } \\
\hline $\begin{array}{c}\text { Cronbach's } \\
\text { Alpha }\end{array}$ & $\begin{array}{l}\mathrm{N} \text { of } \\
\text { Items }\end{array}$ & $\begin{array}{c}\text { Cronbach's } \\
\text { Alpha }\end{array}$ & $\begin{array}{ll}\mathrm{N} & \text { of } \\
\text { Items }\end{array}$ & $\begin{array}{c}\text { Cronbach's } \\
\text { Alpha }\end{array}$ & $\begin{array}{l}\mathrm{N} \text { of } \\
\text { Items }\end{array}$ \\
\hline 0.517 & 22 & 0.609 & 13 & 0.638 & 35 \\
\hline
\end{tabular}

Source: Research data processed with using SPSS program.

\subsection{Exploratory Factor Analysis and Confirmation Factor Analysis}

A factor analysis was conducted on both the people oriented and task oriented replies of managers using varimax with Kaiser Normalization after principal component analysis, extraction method. 22 items for task oriented scales and 13 items for people oriented scales loaded cleanly on to define the factors precisely, except for items T5 and T7 for task and P11 and P13 for people which had factor loadings of less than 0.50 (Hair et al 1998) 22 items for task oriented style dropped to 20 and 13 items for people oriented style dropped to 11 .

In order to determine the factors in the research, on the basis of Catell's (1966) study criterion, factors with eigenvalues greater than 1.0 and factor loadings that are equal to or greater 0.50 were retained. Principle component analysis indicated that an eight-factor solution would be appropriate for task oriented dimensions and four-factor solution would be sufficient for the people oriented dimensions of the study. Below depicted names are given to the grouped factors and results are given below tables 5 and 6 . 


\section{Macrothink}

International Journal of Regional Development ISSN 2373-9851 2014, Vol. 1, No. 1

Table 5. Eigenvalues, initial and after rotated component matrix, R square and Mean scores (Task oriented dimensions)

\begin{tabular}{|c|c|c|c|c|c|c|}
\hline $\begin{array}{l}\text { Task } \\
\text { Oriented } \\
\text { Factors }\end{array}$ & $\begin{array}{l}\text { Task Oriented } \\
\text { Questions }\end{array}$ & Factor Name & $\begin{array}{l}\text { Initial } \\
\text { Eigenvalues }\end{array}$ & $\begin{array}{l}\text { Eigenvalues } \\
\text { After } \\
\text { Rotated } \\
\text { Component } \\
\text { Matrix }\end{array}$ & Mean & $\begin{array}{l}\text { Std. } \\
\text { Deviation }\end{array}$ \\
\hline \multirow{4}{*}{ Factor 1} & T17 & \multirow{4}{*}{ Encouragement } & 19.773 & .775 & 3.3475 & .57963 \\
\hline & T6 & & & .738 & & \\
\hline & T13 & & & .560 & & \\
\hline & T20 & & & .541 & & \\
\hline \multirow{3}{*}{ Factor 2} & T21 & \multirow{3}{*}{ Authoritarian } & 9.832 & .741 & 1.6742 & .46596 \\
\hline & T19 & & & .646 & & \\
\hline & T15 & & & .614 & & \\
\hline \multirow{2}{*}{ Factor 3} & T8 & \multirow{2}{*}{ Decisive } & 7.049 & .800 & 2.9868 & .50797 \\
\hline & T16 & & & .597 & & \\
\hline \multirow{3}{*}{ Factor 4} & T14 & \multirow{3}{*}{ Arbiter } & 6.038 & .711 & 3.1186 & .47711 \\
\hline & $\mathrm{T} 4$ & & & .610 & & \\
\hline & $\mathrm{T} 1$ & & & .589 & & \\
\hline \multirow{2}{*}{ Factor 5} & $\mathrm{~T} 2$ & \multirow{2}{*}{ Supervision } & 5.732 & .747 & 2.3559 & .45449 \\
\hline & T9 & & & .505 & & \\
\hline \multirow{2}{*}{ Factor 6} & T22 & \multirow{2}{*}{ Controller } & 5.607 & .689 & 3.3446 & .59819 \\
\hline & $\mathrm{T} 10$ & & & .595 & & \\
\hline Factor 7 & T11 & Restrictive & 5.318 & .856 & 1.8418 & 1.42934 \\
\hline Factor 8 & $\mathrm{~T} 3$ & Constant & 5.063 & .849 & 3.5989 & .68474 \\
\hline Average & & & & & 2.7835 & \\
\hline R Square & 0.67 & & & & & \\
\hline
\end{tabular}

Source: Research data processed with using SPSS program. 
Table 6. Eigenvalues, initial and after rotated component matrix, R square and Mean scores (people oriented dimensions)

\begin{tabular}{|c|c|c|c|c|c|c|}
\hline $\begin{array}{l}\text { People } \\
\text { Oriented } \\
\text { Factors }\end{array}$ & $\begin{array}{l}\text { People Oriented } \\
\text { Questions }\end{array}$ & Factor Name & $\begin{array}{l}\text { Initial } \\
\text { Eigenvalues }\end{array}$ & \begin{tabular}{|l} 
Eigenvalues \\
After \\
Rotated \\
Component \\
Matrix
\end{tabular} & Mean & $\begin{array}{l}\text { Std. } \\
\text { Deviation }\end{array}$ \\
\hline \multirow{5}{*}{ Factor 1} & P5 & \multirow{5}{*}{ Democratic } & \multirow[t]{2}{*}{26.702} & .790 & 2.4972 & .54527 \\
\hline & $\mathrm{P} 15$ & & & .783 & & \\
\hline & $\mathrm{P} 10$ & & & .753 & & \\
\hline & P3 & & & .659 & & \\
\hline & $\mathrm{P} 24$ & & & .573 & & \\
\hline \multirow{3}{*}{ Factor 2} & $\mathrm{P} 22$ & \multirow{3}{*}{ Tolerance } & 16.019 & .788 & 2.6930 & .43293 \\
\hline & $\mathrm{P} 12$ & & & .654 & & \\
\hline & P9 & & & .584 & & \\
\hline \multirow{2}{*}{ Factor 3} & P31 & \multirow{2}{*}{ Persuasion } & 10.415 & .841 & 2.9689 & .62649 \\
\hline & P16 & & & .587 & & \\
\hline Factor 4 & P6 & Stress & 9.153 & .862 & 1.4350 & .96384 \\
\hline Average & & & & & 2.3985 & \\
\hline R Square & 0.67 & & & & & \\
\hline
\end{tabular}

Source: Research data processed with using SPSS program.

\subsection{Testing the Proposed Conceptual Model}

Model 1 derived from tables 5 and 6 shows that selected task and people oriented factors are statistically significant for the authority levels of the managers. Constant factor (3.60) has the highest effect together with controller (3.35) and encouragement (3.35) factors on overall authority level. It means that a unit change in the response rate of authority level of managers for constant, controller and encouragement items, leads to a positive change in their overall authority rate by 3.60 and 3.35. Furthermore, 67 percent of the variance in the authority level is explained by this model when compared to people orientation $(0.07$ percent of explained variance) Authoritarian is the dependent variable and the Task Orientation 8 Factors are the independent variables. The degree of Linear Relationship between authoritarian and the factors are $\% 32.3$ and the Coefficient of Determination $\left(\mathrm{R}^{2}\right)$ is $\% 10.4$.

The $\mathrm{R}^{2}$ value tells us that $\% 10.4$ of the dependent variable (authoritarian) of total variation is accounted by independent variables (task orientation 8 factors).

F-Value for Task Oriented Leadership is 2.805 with 7 degrees of freedom in the numerator and 169 degrees of freedom in the denominator. The critical value of $F$ is 2.64 when we test the hypothesis at the .01 level of significance.

The computed value of $F$ is 2.805 which is greater than the critical value of 2.64. So we describe the 8 factors, which are given below, of task orientation means are not all equal or 


\section{Macrothink}

the mean scores are not the same in each of the rating groups for task orientation factors.

At last, small p- value of F (.009) indicate strong evidence against the hypothesis 1, so we reject the hypothesis 1 . In the model shown below as it can be seen from the tables each task orientation factors of managers have different affects on authority level.

As it can be seen from the tables 15 and 16 average means scores for task oriented factors (2.7869) is higher than the people oriented mean scores (2.3985).

\section{Task Oriented Factors}

- Encouragement

- Decisive

- Arbiter

- Supervision

- Controller

- Restrictive

- Constant

\section{People Oriented Factors}

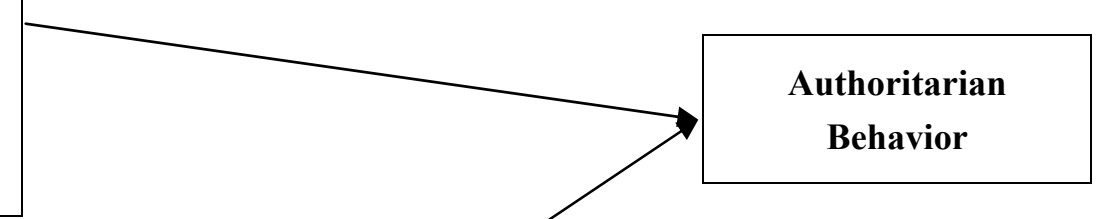

- Democratic

- Tolerance

- Persuasion

- Stress

Figure 2. Model for effect of people oriented and task oriented factors on authoritarian behavior task orientation

Results from the data validate that generally task oriented factors has impact over the authority level while people oriented factors does not affect the authority level of managers. Thus H1: Task oriented factors exert significant effects on authoritarian behaviors were accepted.

At last, small p- value of F (.009) indicate strong evidence against the H2; People oriented factors exert significant effects on authoritarian behaviors were rejected.

\section{4 Research Results to Hypotheses 3-7b}

As shown in the table 7, the majority of the respondents were males aged between 31 to 50 years of age, hold Bachelor degrees, and on average have been employed by the private Banks for 11 years more. Turkey and the TRNC were the dominant countries of origin. 


\section{Macrothink}

Table 7. Demographic data of the respondents

\begin{tabular}{|l|l|l|l|l|l|l|l|l|l|}
\hline Gender & & Age & & Education & & Nationality & & Experience & \\
\hline Female & 80 & Less 30 & 5 & Diploma & 5 & TRNC & 108 & less than 5 & 51 \\
\hline Male & 97 & $31-40$ & 87 & High School & 48 & TR & 64 & $5-10$ & 55 \\
\hline & & $41-50$ & 64 & University & 90 & Others & 5 & $11-15$ & 31 \\
\hline & $\begin{array}{l}51 \quad \text { and } \\
\text { more }\end{array}$ & 21 & $\begin{array}{l}\text { Master } \\
\text { over }\end{array}$ & 34 & & & 16 & and & 40 \\
Total & $\mathbf{1 7 7}$ & & $\mathbf{1 7 7}$ & & $\mathbf{1 7 7}$ & & $\mathbf{1 7 7}$ & & $\mathbf{1 7 7}$ \\
\hline
\end{tabular}

Source: Compiled from data at questionnaire.

\subsection{Means, Frequency and Standard Deviations for Task Oriented Leadership}

Table 8 mean scores and standard deviation for the managers' responses related to task related questions. The mean values ranged from 1.54 to 4.75 and the standard deviation from 0.487 to 1.429 . Average standard deviation is 0.795 and total average mean score for the task oriented behavior is 3.83 which mean manager in TRNC banking sector shows tendency for task orientation.

Taking in to consideration of the responses "Always", it seems that there is a common and high level of acceptance on the T13,T5 and T3 which means manager have tendency to push the employees for increased production, encourage the followers for greater efforts, and encourage the use uniform procedures. While there is lowest agreement on the questions T19 and T21 which refers that, managers don't have attitude to explain the actions and consult the group. 
Table 8. Means, frequency and standard deviations for task oriented leadership

\begin{tabular}{|c|c|c|c|c|c|c|c|c|c|c|c|c|}
\hline \multirow{3}{*}{$\mathbf{Q}$} & \multicolumn{10}{|c|}{ Measurements } & \multirow{3}{*}{ Mean } & \multirow{3}{*}{ S.D } \\
\hline & \multicolumn{2}{|r|}{$\mathbf{A}$} & \multicolumn{2}{|r|}{$\mathbf{F}$} & \multicolumn{2}{|r|}{$\mathbf{O}$} & \multicolumn{2}{|r|}{$\mathbf{S}$} & \multicolumn{2}{|r|}{$\mathbf{N}$} & & \\
\hline & $\mathbf{F}$ & $\%$ & $\mathbf{F}$ & $\%$ & $\mathbf{F}$ & $\%$ & $\mathbf{F}$ & $\%$ & $\mathbf{F}$ & $\%$ & & \\
\hline $\mathrm{T} 1$ & 54 & $30,51 \%$ & 91 & $51,41 \%$ & 29 & $16,38 \%$ & 1 & $0,56 \%$ & 2 & $1,13 \%$ & 4,10 & ,766 \\
\hline $\mathrm{T} 2$ & 9 & $5,08 \%$ & 31 & $17,51 \%$ & 94 & $53,11 \%$ & 37 & $20,90 \%$ & 6 & $3,39 \%$ & 3,00 & ,853 \\
\hline $\mathrm{T} 3$ & 124 & $70,06 \%$ & 37 & $20,90 \%$ & 14 & $7,91 \%$ & 2 & $1,13 \%$ & - & - & 4,60 & ,685 \\
\hline $\mathrm{T} 4$ & 60 & $33,90 \%$ & 84 & $47,46 \%$ & 32 & $18,08 \%$ & 1 & $0,56 \%$ & - & - & 4,15 & ,724 \\
\hline T5 & 127 & $71,75 \%$ & 35 & $19,77 \%$ & 13 & $7,34 \%$ & 2 & $1,13 \%$ & - & - & 4,62 & 673 \\
\hline T6 & 104 & $58,76 \%$ & 53 & $29,94 \%$ & 13 & $7,34 \%$ & 2 & $1,13 \%$ & 5 & $82 \%$ & 4,41 & ,894 \\
\hline $\mathrm{T} 7$ & 15 & $8,47 \%$ & 95 & $53,67 \%$ & 62 & $35,03 \%$ & 5 & $2,82 \%$ & - & - & 3,68 & ,668 \\
\hline $\mathrm{T} 8$ & 49 & $27,68 \%$ & 74 & $41,81 \%$ & 36 & $20,34 \%$ & 12 & $6,78 \%$ & 6 & $3,39 \%$ & 3,84 & 1,018 \\
\hline T9 & 12 & $6,78 \%$ & 14 & $7,91 \%$ & 80 & $45,20 \%$ & 44 & $24,86 \%$ & 27 & $15,25 \%$ & 2,66 & 1,049 \\
\hline $\mathrm{T} 10$ & 74 & $41,81 \%$ & 66 & $37,29 \%$ & 33 & $18,64 \%$ & 4 & $2,26 \%$ & - & $0,00 \%$ & 4,19 & ,815 \\
\hline $\mathrm{T} 11$ & 36 & $20,34 \%$ & 19 & $10,73 \%$ & 44 & $24,86 \%$ & 37 & $20,90 \%$ & 41 & $23,16 \%$ & 2,84 & 1,429 \\
\hline $\mathrm{T} 12$ & 14 & $7,91 \%$ & 87 & $49,15 \%$ & 70 & $39,55 \%$ & 3 & $1,69 \%$ & 3 & $1,69 \%$ & 3,60 &, 733 \\
\hline $\mathrm{T} 13$ & 139 & $78,53 \%$ & 33 & $18,64 \%$ & 4 & $2,26 \%$ & 1 & $0,56 \%$ & - & - & 4,75 &, 517 \\
\hline $\mathrm{T} 14$ & 32 & $18,08 \%$ & 133 & $75,14 \%$ & 12 & $6,78 \%$ & - & - & - & - & 4,11 &, 487 \\
\hline $\mathrm{T} 15$ & 62 & $35,03 \%$ & 92 & $51,98 \%$ & 22 & $12,43 \%$ & 1 & $0,56 \%$ & - & - & 4,21 & ,674 \\
\hline $\mathrm{T} 16$ & 107 & $60,45 \%$ & 58 & $32,77 \%$ & 10 & $5,65 \%$ & 2 & $1,13 \%$ & - & - & 4,53 & ,658 \\
\hline $\mathrm{T} 17$ & 50 & $28,25 \%$ & 81 & $45,76 \%$ & 42 & $23,73 \%$ & 4 & $2,26 \%$ & - & - & 4,00 & ,783 \\
\hline $\mathrm{T} 18$ & 102 & $57,63 \%$ & 50 & $28,25 \%$ & 22 & $12,43 \%$ & 1 & $0,56 \%$ & 2 & $1,13 \%$ & 4,41 &, 814 \\
\hline T19 & - & - & 5 & $2,82 \%$ & 18 & $10,17 \%$ & 45 & $25,42 \%$ & 109 & $61,58 \%$ & 1,54 &, 790 \\
\hline $\mathrm{T} 20$ & 84 & $47,46 \%$ & 62 & $35,03 \%$ & 21 & $11,86 \%$ & 8 & $4,52 \%$ & 2 & $1,13 \%$ & 4,23 & ,909 \\
\hline $\mathrm{T} 21$ & - & - & 10 & $5,65 \%$ & 64 & $36,16 \%$ & 66 & $37,29 \%$ & 37 & $20,90 \%$ & 2,27 & ,855 \\
\hline $\mathrm{T} 22$ & 108 & $61,02 \%$ & 52 & $29,38 \%$ & 15 & $8,47 \%$ & 2 & $1,13 \%$ & - & - & 4,50 & ,700 \\
\hline Aver & & & & & & & & & & & $\mathbf{3 , 8 3}$ &, 795 \\
\hline
\end{tabular}

Source: Research data processed with using SPSS program.

\subsection{Means, Frequency, Standard Deviations for People Oriented Leadership}

Table 9 shows the data related to the answer of managers about the questions related to people oriented leadership styles.

The mean values ranged from 2.25 to 4.64 and the standard deviation from 0.651 to 0.964 . Average standard deviation is .790 and total average mean score for the task oriented behavior is 3.57 which mean manager in TRNC banking sector shows lower tendency for people orientation. There is high agreement on the questions P4 and P8 which refers that they try out their ideas in the group and settle conflicts when occur in the group while low agreement on questions P6, P3 and P10. They have stress being ahead of competing groups, tolerate postponements and uncertainty, and allow the group a high degree of initiative. 
Table 9. Means, Frequency and standard deviations for people oriented leadership

\begin{tabular}{|c|c|c|c|c|c|c|c|c|c|c|c|c|}
\hline \multirow{3}{*}{$\mathbf{Q}$} & \multicolumn{10}{|c|}{ Measurements } & \multirow{3}{*}{ Mean } & \multirow{3}{*}{ S.D } \\
\hline & \multicolumn{2}{|l|}{ A } & \multicolumn{2}{|l|}{$\mathbf{F}$} & \multicolumn{2}{|l|}{$\mathbf{O}$} & \multicolumn{2}{|l|}{ S } & \multicolumn{2}{|l|}{$\mathbf{N}$} & & \\
\hline & $\mathbf{F}$ & $\%$ & $\mathbf{F}$ & $\%$ & $\mathbf{F}$ & $\%$ & $\mathbf{F}$ & $\%$ & $\mathbf{F}$ & $\%$ & & \\
\hline $\mathrm{P} 1$ & 27 & $15,25 \%$ & 86 & $48,59 \%$ & 59 & $33,33 \%$ & 4 & $2,26 \%$ & 1 & $0,56 \%$ & 3,76 &, 756 \\
\hline $\mathrm{P} 2$ & 24 & $13,56 \%$ & 81 & $45,76 \%$ & 66 & $37,29 \%$ & 6 & $3,39 \%$ & - & 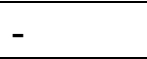 & 3,69 &, 744 \\
\hline $\mathrm{P} 3$ & 5 & $2,82 \%$ & 13 & $7,34 \%$ & 68 & $38,42 \%$ & 59 & $33,33 \%$ & 32 & $18,08 \%$ & 2,44 & ,964 \\
\hline $\mathrm{P} 4$ & 127 & $71,75 \%$ & 41 & $23,16 \%$ & 5 & $2,82 \%$ & 4 & $2,26 \%$ & - & - & 4,64 &, 651 \\
\hline $\mathrm{P} 5$ & 15 & $8,47 \%$ & 71 & $40,11 \%$ & 79 & $44,63 \%$ & 10 & $5,65 \%$ & 2 & $1,13 \%$ & 3,49 &, 777 \\
\hline P6 & 4 & & 10 & & 56 & $31,64 \%$ & 64 & $36,16 \%$ & 43 & $24,29 \%$ & 2,25 &, 964 \\
\hline P7 & 11 & 6,2 & 74 & $\%$ & 80 & $0 \%$ & 11 & $6,21 \%$ & 1 & $0,56 \%$ & 3,47 &, 731 \\
\hline $\mathrm{P} 8$ & 113 & $63,84 \%$ & 44 & $24,86 \%$ & 14 & $7,91 \%$ & 6 & $3,39 \%$ & - & - & 4,49 &, 784 \\
\hline $\mathrm{P9}$ & 68 & $38,42 \%$ & 78 & $44,07 \%$ & 26 & $14,69 \%$ & 5 & $2,82 \%$ & - & - & 4,18 &, 784 \\
\hline $\mathrm{P} 10$ & 5 & $2,82 \%$ & 40 & $22,60 \%$ & 101 & $57,06 \%$ & 25 & $14,12 \%$ & 6 & $3,39 \%$ & 3,07 &, 784 \\
\hline P11 & 38 & $21,47 \%$ & 106 & $59,89 \%$ & 30 & $16,95 \%$ & 3 & $1,69 \%$ & - & - & 4,01 &, 674 \\
\hline $\mathrm{P} 12$ & 18 & $10,17 \%$ & 65 & $36,72 \%$ & 74 & $41,81 \%$ & 18 & $10,17 \%$ & 2 & $1,13 \%$ & 3,45 &, 852 \\
\hline $\mathrm{P} 13$ & 18 & $10,17 \%$ & 62 & $35,03 \%$ & 82 & $46,33 \%$ & 14 & $7,91 \%$ & 1 & $0,56 \%$ & 3,46 &, 805 \\
\hline Average & & & & & & & & & & & 3,57 &, 790 \\
\hline
\end{tabular}

Source: Research data processed with using SPSS program.

The consequences show that the managers in the TRNC banking sector have tendency to task oriented leadership style. (H3 Managers in the banking sector display task oriented action) accepted.

\section{7 Hypothesis results $4 a-4 b$}

There are 30 respondents who work in international banks in managerial positions. Means and standard deviation for the task oriented questions ranged from 1.57 to 4.73 and from 0.450 to 1.402 with average 3.77 and 0.80 respectively. While means and standard deviation for the people oriented questions ranged 2.30 to 4.67 means and 0.661 to 1.093 with average 3.55 means and 0.85 standard deviation.

Results show that international bank managers prefer more task oriented leadership style so our hypothesis. (H4a International bank managers shows more task oriented leadership style) accepted.

There are 108 respondents who work in local banks in managerial positions. Means and standard deviation for the task oriented questions ranged from 1.51 to 4.79 and from 0.524 to 1.480 with average 3.86 and 0.80 respectively. While means and standard deviation for the people oriented questions ranged 2.31 to 4.61 means and 0.699 to 0.971 with average 3.59 means and 0.81 standard deviation.

(H4b Local bank managers shows more people oriented leadership style) rejected. 


\subsection{Hypothesis Results 5}

There are 123 managers respondent with Bachelor of Science and Master of Science. Means and standard deviation for the task oriented questions ranged from 1.54 to 4.76 and from 0.44 to 1.335 with average 3.82 and 0.76 respectively. While means and standard deviation for the people oriented questions ranged 2.20 to 4.65 means and 0.565 to 0.978 with average 3.58 means and 0.75 standard deviation.

(H5 Managers with higher education level tend to be more people oriented leadership style) rejected.

\subsection{Hypothesis Results $6 a-6 b$}

There are 97 male manager respondents. Means and standard deviation for the task oriented questions ranged from 1.58 to 4.69 and from 0.439 to 1.344 with average 3.78 and 0.81 respectively. While means and standard deviation for the people oriented questions ranged 2.33 to 4.62 means and 0.631 to 0.980 with average 3.61 means and 0.79 standard deviation.

Results support our hypothesis.

(H6a Male managers behave more tasks oriented leadership styles) accepted.

There are 80 female manager respondents. Means and standard deviation for the task oriented questions from the female respondents ranged from 1.50 to 4.83 and from 0.414 to 1.522 with average 3.89 and 0.76 respectively. While means and standard deviation for the people oriented questions ranged 2.16 to 4.69 means and 0.612 to 0,999 with average 3.52 means and 0.77 standard deviation.Results do not support our hypothesis. (H6b female managers behave more people oriented leadership styles) rejected.

\subsection{Hypothesis Results $7 a-7 b$}

There are 85 respondents who are more than forty years old related to task oriented and people oriented leadership styles. Means and standard deviation for the task oriented questions from the respondents ranged from 1.51 to 4.80 and from 0.439 to 1.485 with average 3.88 and 0.80 respectively. While means and standard deviation for the people oriented questions ranged 2.16 to 4.81 means and 0.422 to 0.974 with average 3.64 means and 0.78 standard deviation. Results do not support our hypothesis.

(H7a Older managers behave more people oriented leadership styles) rejected.

There are 92 managers who are less than forty years old related to task oriented and people oriented leadership styles. Means and standard deviation for the task oriented questions from the respondents ranged from 1.58 to 4.71 and from 0.515 to 1.342 with average 3.78 and 0.78 respectively. While means and standard deviation for the people oriented questions ranged 2.34 to 4.49 means and 0.618 to 1.006 with average 3.51 means and 0.79 standard deviation.

Results are in accordance with our hypothesis.

(H7b Younger managers behave more task oriented leadership styles) accepted. 


\section{Macrothink}

International Journal of Regional Development

ISSN 2373-9851

2014, Vol. 1, No. 1

Summary of the different leadership styles of the managers working in banking sector in a small island economy are depicted at the matrix shown in the figure 3 . Bearing in mind the difficulty of finding well trained banking staff, economy of scale, isolation, and special conditions in the TRNC banking sector, this matrix may help general managers to decide on which type of managers will suit their strategy.

Task Oriented Leadership

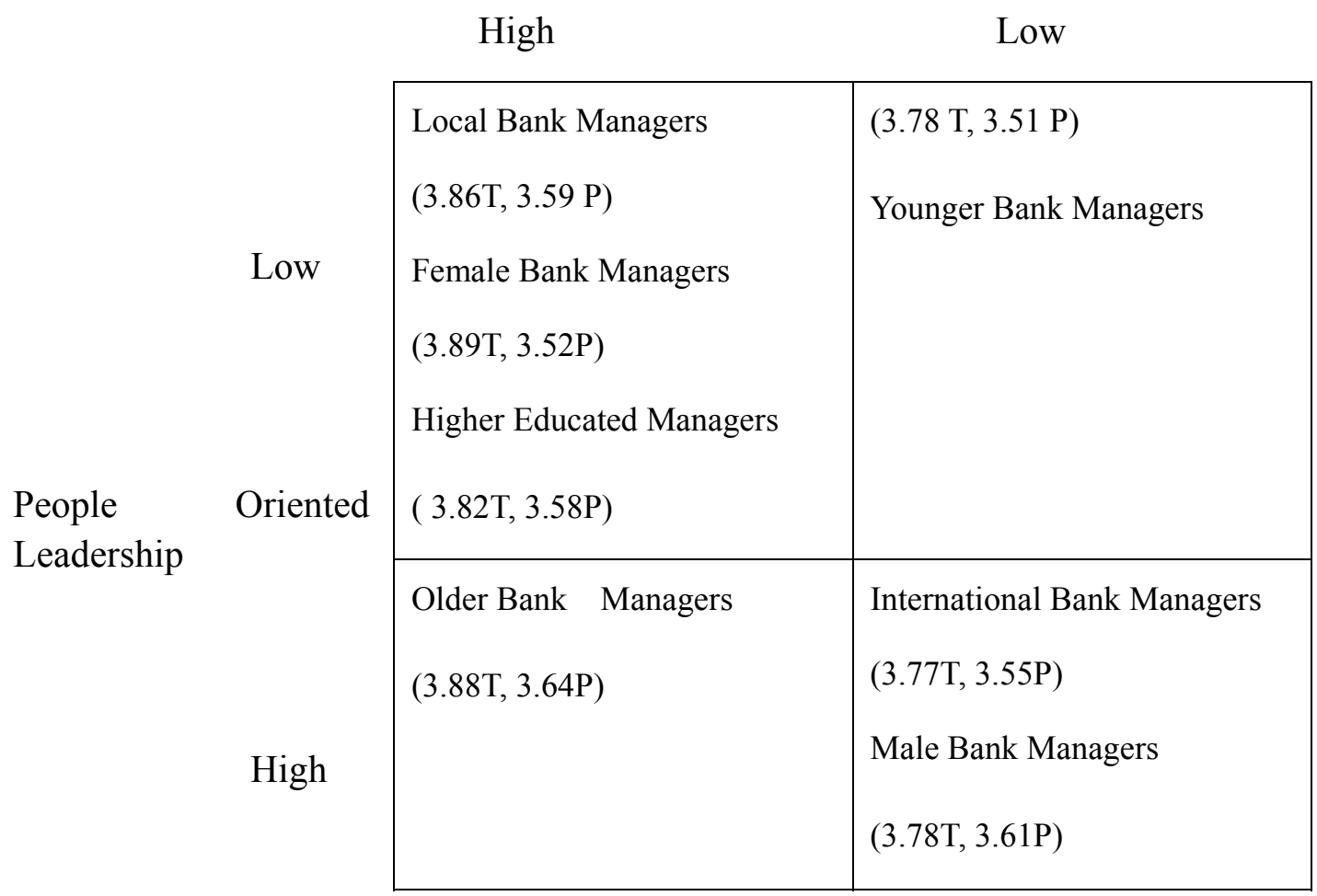

Figure 3. Matrix of Task vs. People oriented leadership style in TRNC

From the results shown in the matrix, it can be stated that female Bank managers' highly prefer the task oriented style and get the highest score ( 3.89 for task) together with the older bank managers ( 3.88 for task).

Older bank managers, who get the highest score (3.64 for people) prefer to show people oriented leadership style, are followed by the male managers with 3.61 score for people oriented style.

Local, female, higher educated managers seem, prefer to take the decision and expect from the followers to obey these decisions and shows task oriented leadership style.

Male, international bank managers prefer to lead people during their office environment and show people oriented leadership style. Young and older bank managers compared with others follows a balanced leadership style.

After all these explanations we may suggest that, Human Resources department and top management may take this matrix into consideration while recruiting the managers who suits their strategy to enhance the performance of the employees. With the help of matrix and the 
model, necessary trainings and educations also may be given to increase managers' unimproved styles in case of decision making or increase or decrease the authoritarian behaviors of managers.

\section{Conclusion and Recommendations}

Every manager is expected and accepted as the leader by the followers. Like many other concepts, the understanding and attitude to leadership styles has developed, changed and evolved over time. Globalization together with the technological revolution affected many industries in one way or another and created a new economy. This new economy with new rules and practices increased the interdependence of the countries and opened new opportunities and challenges. Banking sector inevitably affected by this development should create new strategies and structures in accordance with the needs of the new economy and to face new opportunities and challenges. Leaders / managers need to understand requirements of the new economy and their strengths and their priorities. Globalization and new economy brought its own culture, policies, and systems. Leaders have to understand this development around them in order to consolidate the comparative superiority to the companies that they lead as well as to their competitors.

Banks are profit maximizing organizations and profit maximization, sustainable profitability, creating difference and increasing the capital is important for this sector. Managers have to concentrate on the issues of efficiency and transformation. Because their main duty is create new financial products and services that can compete with their global competitors with the resources in hand. They have to make it in an efficient way. This process has a crucial importance especially in small island economies like North Cyprus bearing in mind the economics of scale.

This research is one of the first studies in North Cyprus to analyze the leadership styles in the banking sector and seeks to contribute towards explanation task oriented and people oriented behaviors of managers. By understanding the leadership styles managers can gain new skills to give better decisions and increase the efficiency of the employees.

Research results show that among task oriented factors (encouragement, decisiveness, arbiter, supervision, controller, restrictiveness and constant) which are tested at the model, constant, controller and encouragement factors have the utmost effect on the authoritarian behaviors of managers. On the other hand people oriented factors (Democratic, Tolerance, persuasion and stress) do not have effect on authoritarian behaviors of managers. Main contribution of this thesis to the literature can be accepted as; factors of the Model which is tested in the research can also be tested in other countries.

Results will make contribution to both practitioners and the management literature in terms of closing the gap in the area of leadership in North Cyprus Banking sector and human resources departments may use these results in managerial development programs. Today's leaders were the followers of yesterday, before coming to manager / leader position; they learned these skills by networking with their supervisors. Understanding and attitude to leadership styles evolved during the time. From this point it may be suggested that effect of 
changing values and tendencies in training and education on leadership development programs related to leadership styles should be studied in broader terms.

Contrary to the previous research findings conducted in Western countries (House, et al 2004; Eagly \& Johnson, 1990) and in Turkey ( Halis, 2003) the current study findings shows that there is a tendency for the task-oriented leadership styles in North Cyprus among female managers. This can be the result of target and/or profitability pressure of the sector. Scarcity of resources may also force managers to exhibit task oriented leadership style to protect their position power and this may affect the employees' performance. Some departments in the banking sector has routine works to be done like accounting, check clearance, reporting etc. and does not subject to rapid changes. Nature of the work may force managers to act task oriented.

Results show that there is tendency to task oriented leadership however there is slight difference between people and task orientation. This may be the result of scarcity of trained human resources. Difficulty in finding well trained human resources in the banking sector may prevent managers to act purely task oriented. As suggested in the matrix human resources departments should design training and development programs for leadership to help leaders how to consolidate people and task oriented styles to increase the efficiency of the followers to achieve the desired objective.

Leadership style fed by the concepts of culture, power, experience, nationality, education and effected by the concepts of age and gender, turn to task or people oriented style. Those who adopt the task oriented style focus on decision making and those who adopt the people oriented style tend to leading people. Research results revealed that due to the intensive competition and due to the effect of density in the banking sector, managers behave more task oriented. However the slight difference of task and people oriented behavior points out that, managers try to reach equilibrium between task orientation and people orientation

As may be happen in other researches, this empirical research has also some restraints. Sample size may be given as the first limitation. The most important one was the difficulty to reach or find data in TRNC. The fact that convenience sampling was used to collect data from the bank managers, may have restricted the possibilities of taking more homogenized sample in terms of gender and other demographic factors.

But despite the above mentioned limitations, findings have provided empirical evidence for leadership behavior for task orientation and people orientation in North Cyprus banking sector. Leaders/ managers in North Cyprus banking sector encourages followers/employees to allow to complete tasks but they do not have strict task orientation or people orientation attitude during this process.

This type of study could be replicated in other sectors such as higher education and tourism which has vital importance for TRNC economy. Impact of organization culture and shape of the organization in leadership style should be studied in broader terms. Bearing in mind the limitations on the banking sector in North Cyprus, the role of external environment factors in creation of leadership style in banking also should be studied. In a different environment 
would the managers behave in a different style?

Relationship between leadership style and banking performance in North Cyprus would be an interesting study topic for future researches.

\section{References}

Abramson, N. R. (2007). The Leadership Archetype: A Jungian Analysis of Similarities between Modern Leadership Theory and the Abraham Myth in the Judaic-Christian Tradition. Journal of Business Ethics, 72, 115-129. http://dx.doi.org/10.1007/s10551-006-9159-5

Bass, B. M. (1967). Social behavior and the orientation inventory: A review. Psychological Bulletin, 68, 260-292. http://dx.doi.org/10.1037/h0025075

Bass, B. M., \& Stogdill. (1990). Handbook of Leadership: Theory (3rd ed.). Research \& Managerial Applications Free Press.

Blake, R., \& Mouton, J. (1964). The Managerial Grid: The key to leadership excellence. Houston, TX: Gulf.

Cannella Jr., A. A., \& Rowe, W. G. (1995). Leader capabilities, succession \& competitive context: A baseball study. The Leadership Quarterly, 1, 69-88. http://dx.doi.org/10.1016/1048-9843(95)90005-5

Cattell, R. B. (1966). The scree test for the number of factors. Multivariate Behavioral Research, 1, 245-276. http://dx.doi.org/10.1207/s15327906mbr0102_10

Daft, R. L. (1998). Organization Theory and Design. South-Western College. Publishing, Cincinnati, Ohio.

DeVellis, R. F. (1991). Scale Development: theory and applications. Applied Social Research Methods Series, 26. Newbury Park: Sage.

Drucker, F. D (2006). What executives should remember? Harvard Business Review, 84(2), 144-166.

Eagly, A. H., \& Johnson, B. T. (1990). Gender and leadership style: A meta-analysis. Psychological Bulletin, 108, 233-256. http://dx.doi.org/10.1037/0033-2909.108.2.233

Fleishman, E. A., Mumford, M. D., Zaccaro, S. J., Levin, K. Y., Korotkin, A. L., \& Hein, M. B. (1991). Taxonomic efforts in the description of leader behavior: A synthesis and functional interpretation. Leadership Quarterly, 2(4), 245-287. http://dx.doi.org/10.1016/1048-9843(91)90016-U

Fiedler, F. E. (1967). A theory of leadership effectiveness. New York: McGraw-Hill

Fornell, C., \& Larcker, D. F. (1981). Evaluating structural equation models with unobservable and measurement error. Journal of Marketing Research, 18(1), 39-50. http://dx.doi.org/10.2307/3151312

Giambatista, R. C. (2004). Jumping through hoops: A longitudinal study of leader life cycle 
in the NBA. The Leadership Quarterly, 15, 607-624. http://dx.doi.org/10.1016/j.leaqua.2004.07.002

Hair, J. F. Jr, Anderson, R. E., Tatham, R. L., \& Black, W. C. (1998). Multivariate Data Analysis (5th ed.). Prentice-Hall, Englewood Cliffs, NJ.

Halis, M. (2003). Leadership Styles in Organizations: Evidence from the Turkish Banking Sector. Akademik Araştırmalar Dergisi 2002-2003 Sayı 15.

Hatcher, L. (1994). A Step-by-Step Approach to Using the SAS® System for Factor Analysis and Structural Equation Modeling. Cary, NC: SAS Institute, Inc.

Hersey, P., \& Blancard, K. H. (1969). Training and Development Journal, 23(5).

House, R. J., Hanges, P. J., Javidan, M., Dorfman, P. W., \& Gupta, V. (2004). Culture, Leadership, and Organizations: The GLOBE Study of 62 Societies. Sage Publications, Inc.

Katz, D. W., \& Maccoby, N. M. (1950). Productivity,Supervision, and Morale in an Office Situation. Detroit. Darel

Kirkpatrick, S. A., \& Locke, E. A. (1996). Direct and indirect effects of three core charismatic leadership components on performance and: attitudes. Journal of Applied Psychology, 81(1), 36-51. http://dx.doi.org/10.1037/0021-9010.81.1.36

Karavelioğlu, A. M. (2009). Banking Crisis in TRNC and Turkish Republic, Dehan Matbası.

Katırcıŏlu, S. T. (2000). The analysis of foreign trade in North Cyprus and its impact on economic growth. unpublished $\mathrm{PhD}$ thesis, Uludağ University, Bursa.

Koçel, T. (2005). Business Management. Arıkan Basım Yayım Dağıtım Ltd. Şti.

Luthans, F. (1995). Organizational Behavior (7th ed.). McGraw-Hill.

McGorry, S. Y. (2000). Measurement in a cross-cultural environment: survey translation issues. Qualitative Market research: An International Journal, 3(2), 74-81. http://dx.doi.org/10.1108/13522750010322070

Mullins, J. L. (1993). Management and Organizational Behaviour (3rd ed.). PITMAN Publishing.

Nahavandi, A. (2006). The art and science of leadership (4th ed.). Pearson Education, Ltd.

Northouse, P. G. (2004). Leadership Theory and Practice (3rd ed.). Sage Publications, Inc.

Nunnally, J. C. (1978). Psychometric theory (2nd ed.). New York: Mc Graw-Hill Book Company.

Rowe, W. G., Cannella Jr., A. A., Rankin, D., \& Gorman, D. (2005). Leader succession \& organizational performance: Integrating the common-sense, ritual scapegoating \& vicious-circle succession theories. The leadership Quarterly, 16(2), 197-219. http://dx.doi.org/10.1016/j.leaqua.2005.01.001 
Stogdill, R. M. (1974). Handbook of leadership: A survey of theory and research Free Press (New York).

Şafakl1, O. V. (2003). Basic Problems of the Banking Sector in the TRNC with Partial Emphasis. Proactive and Reactive Strategies Applied Dogus Üniversitesi Dergisi, 4(2), 217-232.

Ulgen, H., \& Mirze S. K. (2006). Strategic Management in Business. Literatür Yayınc1lık Ltd. Şti.

Yukl, G. (1994). Leadership in Organizations (3rd ed.). Englewood Cliffs, NJ: Prentice-Hal Retrieved from http://www.devplan.org/Nufus-2011/nufus\%20son_.pdf 
Appendix: Survey/Questionnaire in English

\section{LEADERSHIP QUESTIONNAIRE}

ASSESSMENT OF STYLE

This questionnaire has been designed to evaluate the leadership styles TRNC banking sector and the information gathered will be used in the preparation of the doctorate thesis for GAU. The information given is private and confidential and will purely be used for academic purposes. Thank you for taking the time to participate in the questionnaire.

\begin{tabular}{|c|c|c|c|c|c|}
\hline \multicolumn{6}{|l|}{ 1.SECTION } \\
\hline Sex & Male & Female & & & \\
\hline Age & Below 30 & $31-40$ & $41-50$ & Over 51 & \\
\hline Place of Birth & TRNC & TR & \multicolumn{2}{|c|}{ Other. Please specify } & \\
\hline Education & High School & Diploma & University & \multicolumn{2}{|l|}{ MA and over } \\
\hline \multicolumn{2}{|c|}{ How many years are you working in finance sector? } & less then 5 years & 5-10 Years & $11-15$ Years & $16+$ \\
\hline \multicolumn{2}{|c|}{ How many years are you working as manager? } & less then 5 years & 5-10 Years & 11-15 Years & $16+$ \\
\hline The Bank you working is & Statebank & \multirow{2}{*}{$\begin{array}{l}\text { Private bank } \\
\text { Unit manager }\end{array}$} & Branch bank & & \\
\hline Your Title & Manager & & Ass. Gen. M & General Manager & \\
\hline
\end{tabular}

\section{SECTION}

The following items decribe aspects of leadership behavior. Respond to each item according to the way you would most likely act if you were leader of a work group. Circle wheter you would most likely behave in described way.

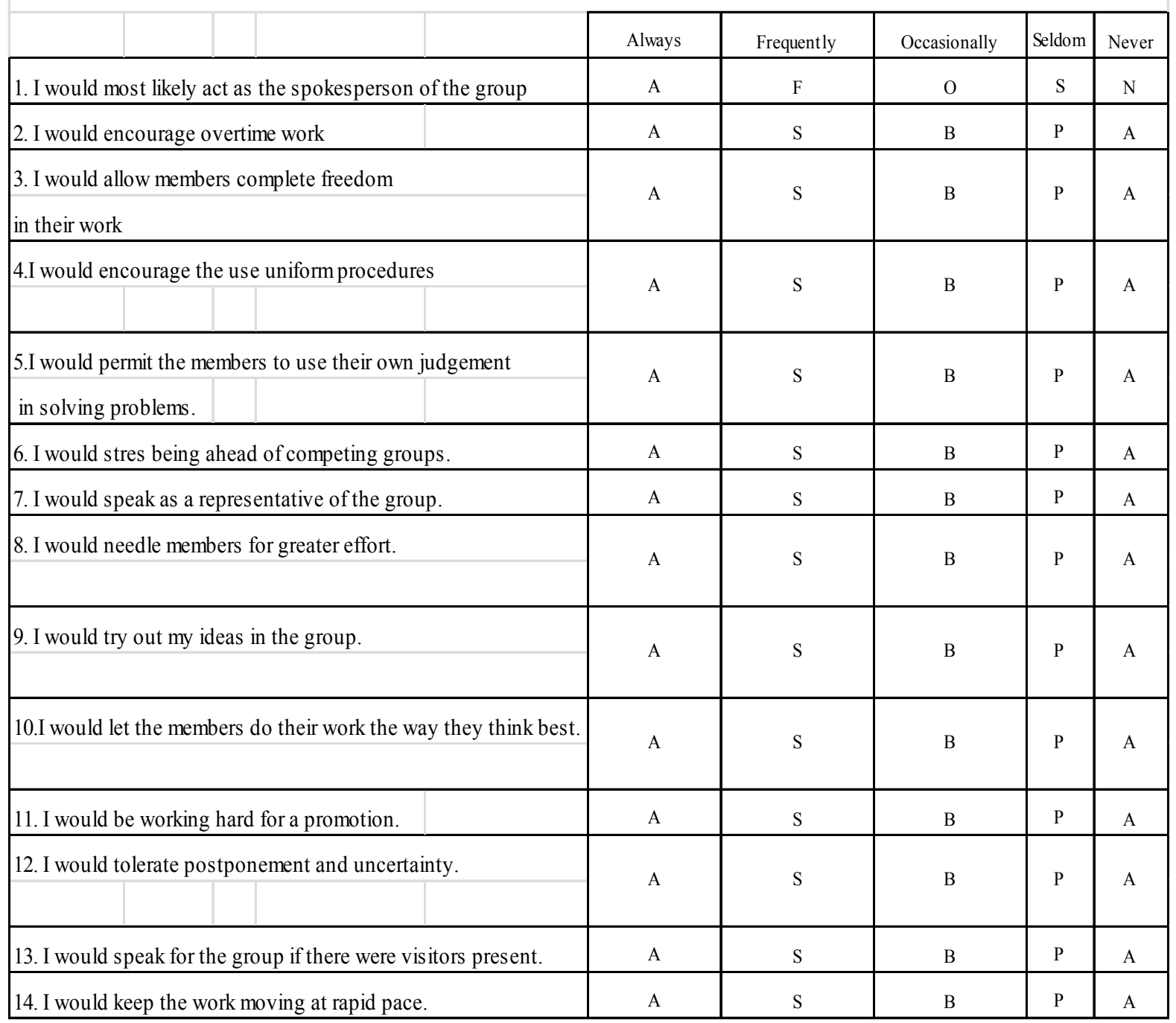




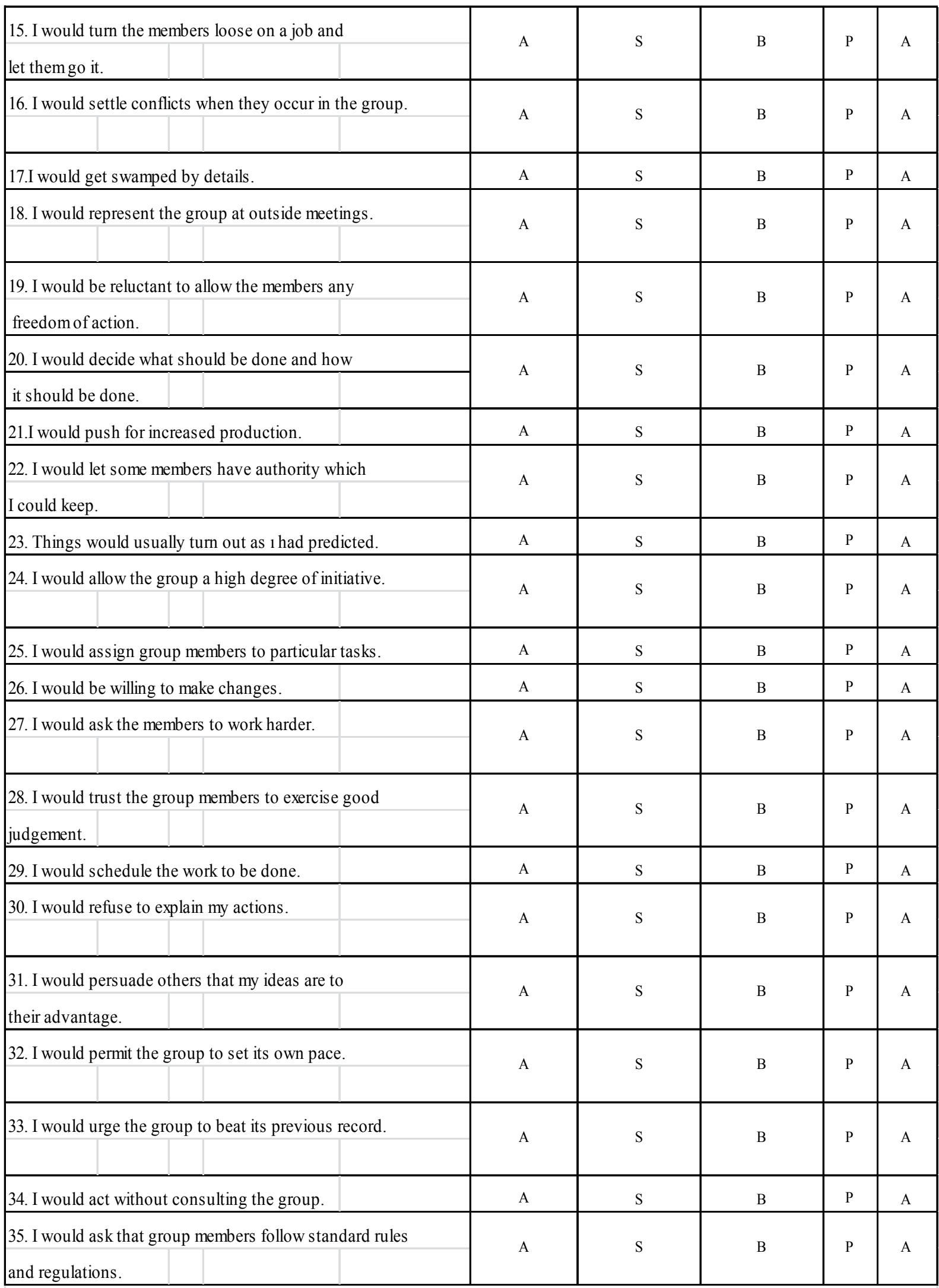




\section{Copyright Disclaimer}

Copyright for this article is retained by the author(s), with first publication rights granted to the journal.

This is an open-access article distributed under the terms and conditions of the Creative Commons Attribution license (http://creativecommons.org/licenses/by/3.0/). 